Al Maal : Journal of Islamic Economics and Banking

http://jurnal.umt.ac.id/index.php/jieb

E-ISSN : $2580-3816$

Vol : 2 No. 2 Bulan Januari Tahun 2021

Hlm : $113-122$

DOI $\quad$ : $10.31000 /$ almaal.v2i2.3565

\title{
Analisis Persepsi Nelayan Perikanan Tangkap Terhadap Pembiayaan Bank Syariah
}

\author{
Muhammad Anhar1,*, Ating Sukma ${ }^{2}$, Sutisna ${ }^{3}$ \\ ${ }^{1,2,3}$ Program Studi Ekonomi Syariah, Fakultas Pascasarjana Universitas Ibn Khaldun Bogor, \\ Indonesia \\ *anhartheeconom@gmail.com
}

\begin{abstract}
Kecamatan Palabuhanratu is a capture fishery base for fishing areas in the South of Sea Java and the Indonesian Exclusive Economic Zone (ZEEI) in the Indian Ocean. As most of fishermen in Indonesia, the majority of fishermen in Palabuhanratu still live in poverty. Poverty is caused by several factors, one of which is capital. The majority of fishermen want to add their capital by using conventional banks or moneylenders who charge them high interest, so they are getting poorer. This study aims to look at fishermen's perceptions of capital financing in Islamic banks. The research method used is the theory of planned behavior analysis (TPB) and structured equation modeling (SEM). The variables used in this study are subjective norms (SN), attitudes toward behavior (ATB), and perceived behavioural control (PBC). The results of data analysis show that SN, ATB, and PBC positively affect fishermen's perceptions of financing in Islamic banks. In addition, the $S N$ and $P B C$ variables positively affect the intention of fishermen to apply for financing in Islamic banks.
\end{abstract}

Keywords: Fisherman; Theory of Planned Behaviour (TPB); Poverty.

\section{ABSTRAK}

Kecamatan Palabuhanratu merupakan basis perikanan tangkap untuk wilayah penangkapan di Laut Selatan Jawa dan Zona Ekonomi Eksklusif Indonesia (ZEEI) di Perairan Samudera Hindia. Sebagaimana nelayan pada umumnya di Indonesia, mayoritas nelayan di Palabuhanratu masih hidup dalam kemiskinan. Kemiskinan disebabkan beberapa faktor, salah satunya adalah permodalan. Mayoritas nelayan menambah modal melalui bank konvensional atau rentenir yang mengenakan bunga tinggi sehingga mereka semakin miskin. Penelitian ini bertujuan untuk melihat persepsi nelayan terhadap pembiayaan modal di bank syariah. Metode penelitian yang digunakan adalah analisis theory of planned behaviour (TPB) dan structured equation modeling (SEM). Variabel yang digunakan dalam penelitian ini adalah norma subyektif (SN), sikap terhadap perilaku (ATB), dan persepsi kontrol perilaku (PBC). Hasil analisis data menunjukkan $S N$, ATB, dan PBC secara positif memengaruhi persepsi nelayan terhadap pembiayaan di bank syariah. Selain itu, peubah SN dan PBC secara positif memengaruhi niat nelayan untuk mengajukan pembiayaan di bank syariah.

Kata kunci: Nelayan; Theory of Planned Behaviour (TPB); Kemiskinan. 


\section{Pendahuluan}

Laut Indonesia memiliki potensi perikanan yang besar. Hal ini dapat dilihat dari potensi lestari sumber daya ikan atau Maximum Sustainable Yield (MSY) sebesar 7,3 ton per tahun, dengan jumlah tangkapan yang diperbolehkan atau Total Allowable Catch (TAC) sebesar 5,8 juta ton per tahun setara $80 \%$ dari MSY. Namun, potensi besar ini baru dimanfaatkan sebesar 5,4 juta ton pada tahun 2013 atau sekitar 93\% dari TAC. Ini menandakan potensi laut yang dimiliki Indonesia belum tereksplorasi secara penuh sebagai penyangga pangan fungsional pada masa depan (Setiyowati dkk 2016).

Kecamatan Palabuhanratu merupakan basis perikanan tangkap di Laut Selatan Jawa dan Zona Ekonomi Eksklusif Indonesia (ZEEI) di Perairan Samudera Hindia. Oleh karena itu, sebagian besar masyarakat di Palabuhanratu berprofesi sebagai nelayan untuk memenuhi kebutuhan hidup dan keluarganya (Guritno dkk 2014). Potensi hasil perikanan tangkap yang besar di Palabuhanratu tidak menjadikan masyarakat yang hidup di sana sejahtera, melainkan masih mengalami kemiskinan (Retnowati 2011). Penyebab dari kemiskinan yang dialami nelayan setidaknya ada 5 faktor, yaitu kesenjangan yang terjadi antar nelayan, keterbatasan wilayah tangkap, cuaca serta musim, perilaku konsumtif nelayan, dan keterbatasan alat tangkap yang disebabkan oleh kurangnya modal (Fadillah dan Kurnia 2018).

Nelayan merupakan pekerjaan yang sangat dekat dengan risiko krisis dan ketidakpastian. Menurut Mirajiani dkk (2014) kurang lebih ada 5 faktor yang menyebabkan risiko krisis dan ketidakpastian (crisis risk and uncertainty) tersebut. Pertama, kegiatan melaut nelayan sangat dipengaruhi cuaca dan iklim. Nelayan hanya akan melaut saat cuaca bagus. Kedua, hasil tangkapan nelayan sangat bergantung dengan sumber daya laut yang ada saat ini, dimana jumlah dan ukurannya dipengaruhi oleh perubahan global seperti perubahan iklim atau ulah tangan manusia yang menangkapnya saat ukuran belum besar. Ketiga, nelayan belum menguasai teknologi perikanan yang paling baru sehingga masih menggunakan kapal dan alat tangkap tradisional. Keempat, nelayan masih mempunyai masalah dalam penyediaan sarana dan prasarana seperti cold storage yang belum memadai. Terakhir atau yang kelima, nelayan di Indonesia masih bergantung dengan ketersediaan modal finansial.

Imron (2003) mengatakan bahwa terdapat 2 kategori kemiskinan pada masyarakat nelayan. Kategori pertama merupakan kemiskinan prasarana. Hal ini dapat dilihat dari kondisi fisik desa-desa nelayan yang mengalami kekurangan air bersih, jauhnya pasar dari pelabuhan, dan tidak adanya akses untuk mendapatkan bahan bakar dengan harga standar. Faktor prasarana ini secara tidak langsung akan menyebabkan kemiskinan seperti uang yang harusnya untuk membeli bahan bakar digunakan untuk membeli air bersih terlebih dahulu. Kategori kedua adalah kemiskinan keluarga yang penyebabnya juga berasal dari kemiskinan prasarana.

Kurangnya modal melaut menyebabkan nelayan mengajukan pinjaman kepada rentenir atau pembiayaan ke bank konvensional. Akses pembiayaan ke bank konvensional biasanya terbatas dan adanya agunan yang membuat nelayan memilih rentenir (Masyhuri 2014). Rentenir dipilih nelayan sebagai jalan pintas karena kemudahan pencairan dananya. Namun, nelayan tidak sadar bahwa bunga yang ditetapkan rentenir berkisar antara 20-40\% (Syafrini 2014). Bunga yang tinggi tidak menjadi solusi kurangnya modal tetapi justru menjadi masalah baru yang menyebabkan mereka semakin miskin. 
Alternatif lain yang dapat menjadi solusi dari pembiayaan modal bagi nelayan melalui pembiayaan di bank bank syariah. Namun, kurangnya sosialisasi dan juga promosi dari bank syariah menyebabkan minimnya informasi ini diterima oleh nelayan (Fadillah dan Kurnia 2018).

Penelitian ini bertujuan untuk menganalisis pengetahuan nelayan tentang bank syariah dan persepsi nelayan terhadap pembiayaan di bank syariah, khususnya dengan menggunakan Theory Of Planned Behavior (TPB).

\section{KAJIAN LITERATUR Pembiayaan Berbasis Syariah}

Pembiayaan saat ini menjadi sebuah senjata ekonomi, sosial dan politik karena peranannya bukan hanya untuk mengalokasikan dan mendistribusikan sumber-sumber daya langka, tetapi juga menjaga stabilitas dan pertumbuhan ekonomi. Reformasi sosioekonomi niscaya tidak akan berarti kecuali menimbulkan kemungkinan bagi lembagalembaga keuangan untuk memberikan kontribusi maksimal sehingga dapat mewujudkan sumber daya keuangan yang merata dan efisien (Chapra 2006).

Pembiayaan merupakan salah satu tugas pokok bank untuk memberikan fasilitas dana dalam memenuhi kebutuhan pihak-pihak yang defisit unit. Ada dua pola pembiayaan utama di bank syariah, yaitu pembiayaan jual beli dan pembiayaan bagi hasil. Dalam statistik perbankan syariah yang diterbitkan Bank Indonesia, ada tiga akad atau perjanjian yang digunakan dalam pembiayaan, yaitu akad murabahah, mudharabah, dan musyarakah (Ranianti dan Ratnawati 2014).

\section{Theory of Planned Behaviour (TPB)}

Model Teori Perilaku Terencana (Theory of Planned Behaviour) secara sederhana menjelaskan bahwa faktor utama yang dapat memengaruhi perilaku seseorang adalah niat atau kecenderungannya untuk melakukan suatu tindakan (Sumarwan 2011). Dorongan niat itu yang akan menyebabkan seorang konsumen mengambil sebuah keputusan yang dalam penelitian ini adalah pengajuan pembiayaan kepada bank syariah.

Teori ini menjelaskan bahwa sikap serta norma subyektif seseorang terhadap perilakunya akan memengaruhi minat. Faktor tambahan lainnya yang akan memengaruhi minat konsumen adalah pengendalian persepsi perilaku. Oleh karena itu, TPB akan menunjukkan bahwa tindakan tertentu seorang individu dipengaruhi minatnya melakukan tindakan tersebut (Asmarani 2012).

\section{Metode Penelitian}

Penelitian yang dilakukan merupakan penelitian survei. Penulis melakukan wawancara dengan menggunakan kuesioner kepada para responden. Metode yang akan digunakan adalah metode penelitian deskriptif. Pendekatan survei dilakukan dengan mengajukan daftar pertanyaan berupa kuesioner kepada responden. Penelitian dilakukan pada bulan Mei, September, dan Oktober 2017.

Populasi dalam penelitian ini adalah seluruh nelayan perikanan tangkap yang berdomisili di Kecamatan Palabuhanratu, Kabupaten Sukabumi dan telah berpengalaman melaut minimal satu tahun. Jumlah penduduk di Kecamatan Palabuhanratu yang 
berprofesi sebagai nelayan pada tahun 2016 berjumlah 1.437 orang (Joel 2017). Setelah itu, jumlah sampel ditentukan menggunakan rumus slovin sebagai berikut:

$$
n=\frac{N}{1+N(e)^{2}}
$$

Keterangan:

$\mathrm{n}=$ jumlah responden

$\mathrm{N}=$ ukuran populasi

$\mathrm{e}=$ persentase kelonggaran ketelitian kesalahan pengambilan sampel yang masih bisa ditolerir

Metode pengambilan sampel menggunakan metode nonprobability sampling, dimana peluang untuk memilih unit contoh tidak diketahui. Pemilihan responden menggunakan teknik snowball sampling, yaitu sampel awal diambil dengan metode probability, sedangkan tambahan sampel diperoleh dari referensi sampel awal terpilih (Tanjung dan Abrista 2013).

Indikator yang digunakan dalam penelitian ini berjumlah 18 indikator yang diharapkan mampu menggambarkan tujuh variabel dari theory of planned behaviour (TPB). Pengukuran indikator menggunakan skala likert 1-7 untuk menggambarkan tingkat persepsi nelayan sebagai responden. Indikator pengukuran dapat dilihat pada Tabel 1.

Tabel 1. Variabel dan Indikator Penelitian

\begin{tabular}{|c|c|c|c|c|}
\hline No & Variabel & & Indikator & Skala \\
\hline \multirow{2}{*}{1.} & Norma Subyektif & 1. & Pengaruh Keluarga & Likert \\
\hline & & 2. & Pengaruh non keluarga & Likert \\
\hline \multirow[t]{2}{*}{2.} & Motivasi & 3. & Mengikuti pengaruh keluarga & Likert \\
\hline & Mematuhi & 4. & Mengikuti pengaruh non keluarga & Likert \\
\hline \multirow[t]{3}{*}{3.} & $\begin{array}{l}\text { Kepercayaan } \\
\text { Terhadap Perilaku }\end{array}$ & 5. & $\begin{array}{l}\text { Pembiayaan syariah merupakan salah satu } \\
\text { cara menerapkan nilai Islam }\end{array}$ & Likert \\
\hline & & 6. & $\begin{array}{l}\text { Pembiayaan syariah dapat memberikan rasa } \\
\text { tenang bagi nelayan }\end{array}$ & Likert \\
\hline & & 7. & $\begin{array}{l}\text { Pembiayaan syariah dapat menghindari } \\
\text { bunga yang berasal dari pinjaman rentenir } \\
\text { dan judi }\end{array}$ & Likert \\
\hline \multirow[t]{3}{*}{4.} & Evaluasi Keluaran & 8. & $\begin{array}{l}\text { Penting menerapkan nilai Islm dalam } \\
\text { kehidupan }\end{array}$ & Likert \\
\hline & & 9. & $\begin{array}{l}\text { Penting menghindari bunga dan judi } \\
\text { Pembiayaan syariah berbeda dengan }\end{array}$ & Likert \\
\hline & & 10. & $\begin{array}{l}\text { pembiayaan dari rentenir atau lembaga } \\
\text { keuangan konvensional }\end{array}$ & Likert \\
\hline
\end{tabular}




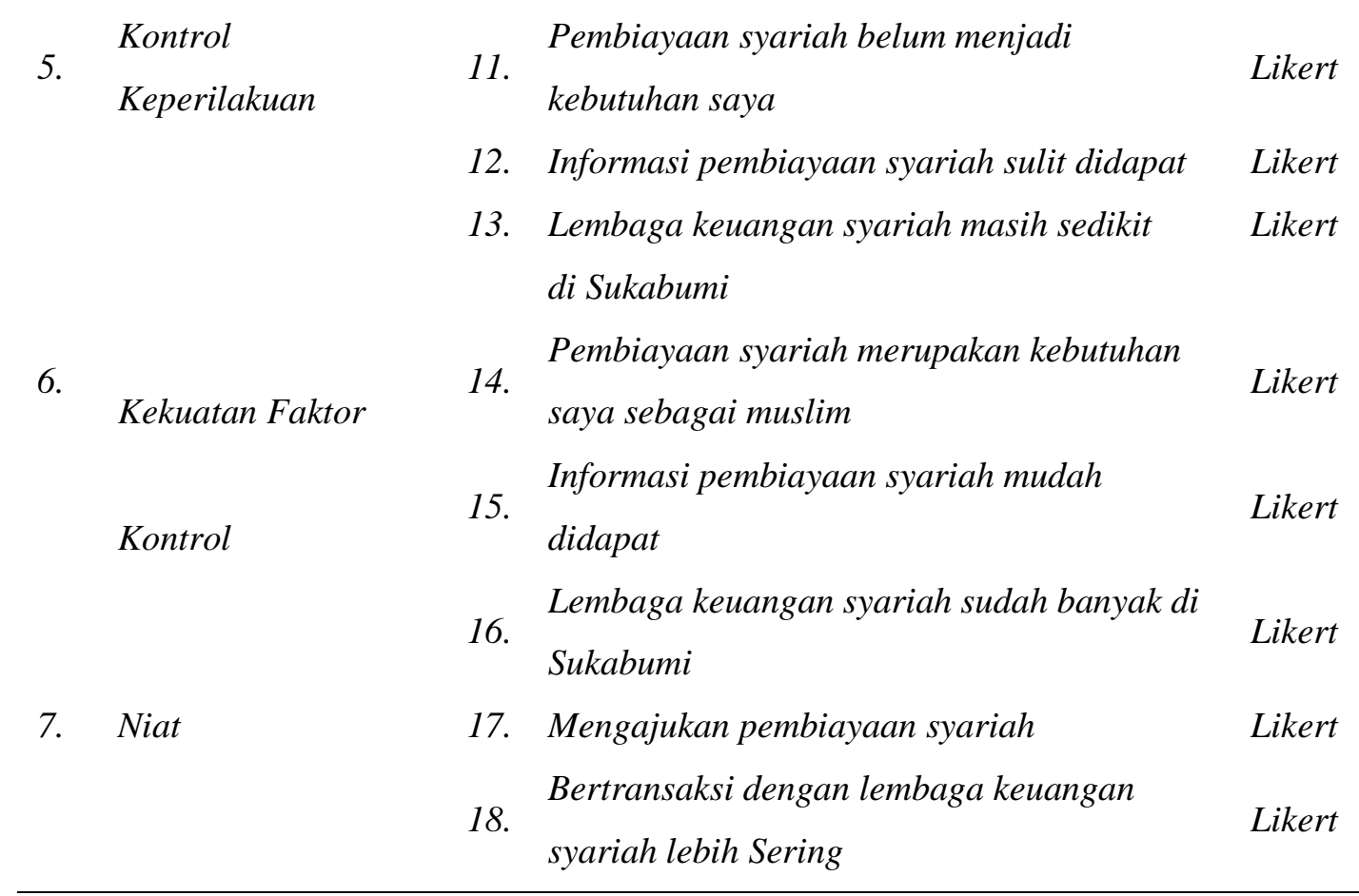

Data hasil wawancara yang telah didapatkan selanjutnya diolah untuk memecahkan masalah yang diteliti. Data kualitatif akan diolah dengan analisis deskriptif. Sedangkan data kuantitatif akan diolah dengan menggunakan statistika inferensia untuk menguji hipotesis.

\section{Hipotesis 1}

$\mathrm{H} 0=$ Subjective Norm tidak berpengaruh terhadap Intention

H1 = Subjective Norm berpengaruh terhadap Intention

Hipotesis pertama adalah variabel subjective norm memiliki pengaruh terhadap intention. Penelitian ini ingin melihat bagaimana pengaruh subjective norm terhadap intention nelayan dalam pengajuan pembiayaan syariah.

\section{Hipotesis 2}

$\mathrm{H} 0=$ Attitude Toward Behaviour tidak berpengaruh terhadap Intention

H1 = Attitude Toward Behaviour berpengaruh terhadap Intention

Hipotesis kedua adalah variabel Attitude Toward Behaviour memiliki pengaruh terhadap intention. Penelitian ini ingin melihat bagaimana pengaruh Attitude Toward Behaviour terhadap intention nelayan dalam pengajuan pembiayaan syariah.

\section{Hipotesis 3}

$\mathrm{H} 0=$ Perceived Behavioural Control tidak berpengaruh terhadap Intention

$\mathrm{H} 1=$ Perceived Behavioural Control berpengaruh terhadap Intention

Hipotesis ketiga adalah variabel Perceived Behavioural Control memiliki pengaruh terhadap intention. Penelitian ini ingin melihat bagaimana pengaruh Perceived Behavioural Control terhadap intention nelayan dalam pengajuan pembiayaan syariah. 


\section{HASil dan Pembahasan Pengetahuan Nelayan Tentang Bank Syariah}

Pengetahuan nelayan akan bank syariah diukur melalui 3 indikator, yaitu mengetahui informasi mengenai bank syariah, telah mempunyai rekening di bank syariah, dan telah menggunakan produk bank syariah selain rekening tabungan. Pengetahuan nelayan akan bank syariah merupakan indikator awal untuk mengetahui persepsi mereka tentang pembiayaan di bank syariah. Kuesioner yang disebar dalam penelitian ini berjumlah 80 eksemplar.

Dari 80 orang nelayan yang telah diwawancarai diketahui bahwa sebanyak 47\% atau 38 orang telah mengetahui informasi tentang bank syariah. Sedangkan sisanya belum mengetahui tentang informasi bank syariah (Gambar 1). Mayoritas responden lebih mengenal dan mengetahui bank konvensional. Kurangnya informasi ini disebabkan tidak adanya kantor bank syariah di Kecamatan Palabuhanratu dan kurangnya promosi dari bank syariah sendiri yang berkaitan dengan produknya kepada nelayan. Promosi yang dilakukan kepada masyarakat nelayan kebanyakan dilakukan bank konvensional dan lebih menarik minat mereka.

Gambar 1. Pengetahuan Nelayan terhadap Informasi Bank Syariah

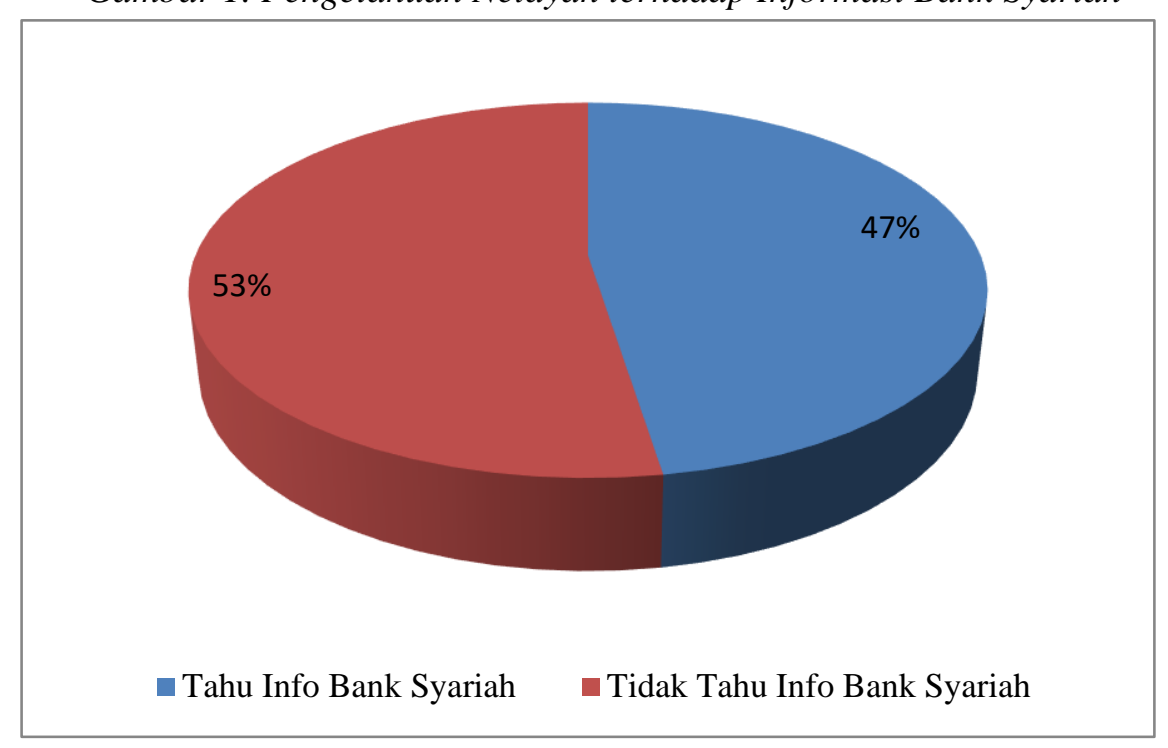

Sumber: data diolah oleh penulis

Berdasarkan hasil wawancara berikutnya diketahui bahwa sebanyak hanya $1 \%$ atau 1 orang yang memiliki rekening di bank syariah. Sisanya sebanyak 99\% atau 79 orang tidak memiliki rekening di bank syariah (Gambar 2).

Penyebab mayoritas nelayan tidak memiliki rekening di bank syariah adalah banyaknya pengeluaran untuk kebutuhan sehari-hari, baik untuk keluarga maupun modal melaut, tidak berpikir kebutuhan di masa depan, dan tidak pernah diajarkan untuk menabung serta mengelola uang dengan baik. Nelayan sudah merasa pusing dengan pengeluaran untuk kebutuhan keluarga dan modal melaut sehingga tidak terpikirkan untuk menyisihkan sebagian pendapatan agar ditabung. 
Gambar 2. Kepemilikan Tabungan oleh Nelayan di Bank Syariah

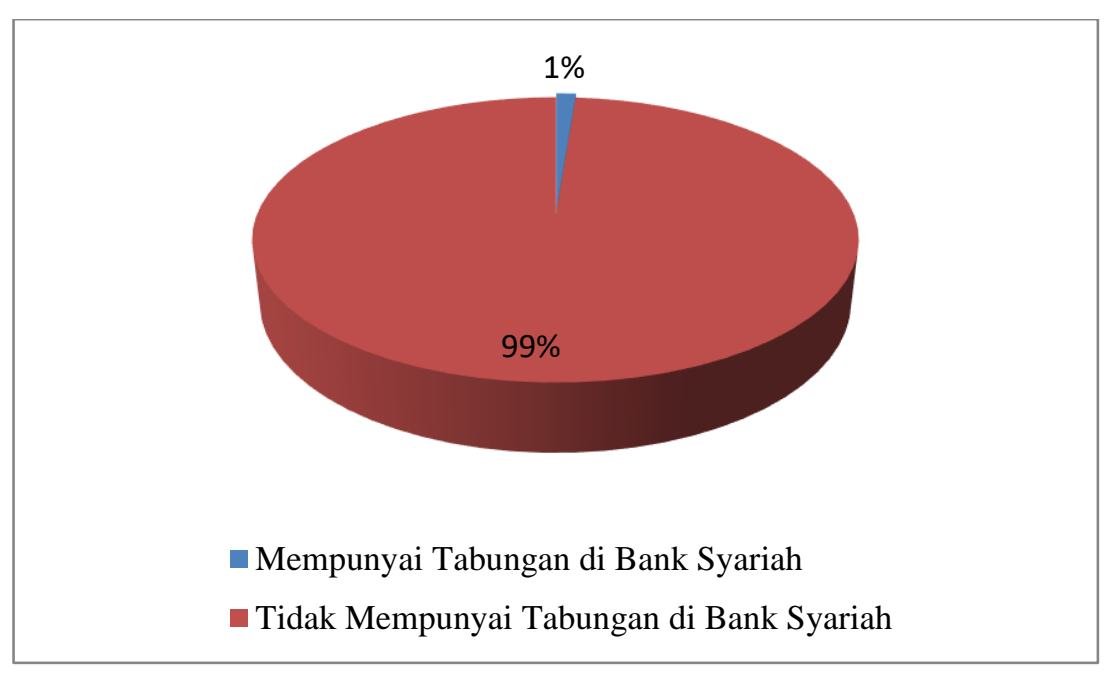

Sumber: data diolah oleh penulis

Penggunaan produk bank syariah selain rekening tabungan juga masih minim. Hal ini dapat dilihat dari Gambar 3 bahwa hanya 5\% atau 4 orang yang pernah menggunakan produk bank syariah selain rekening tabungan. Produk yang digunakan mereka adalah pembiayaan dan disebabkan ajakan dari orang dekat.

Gambar 3. Penggunaan Produk Bank Syariah oleh Nelayan

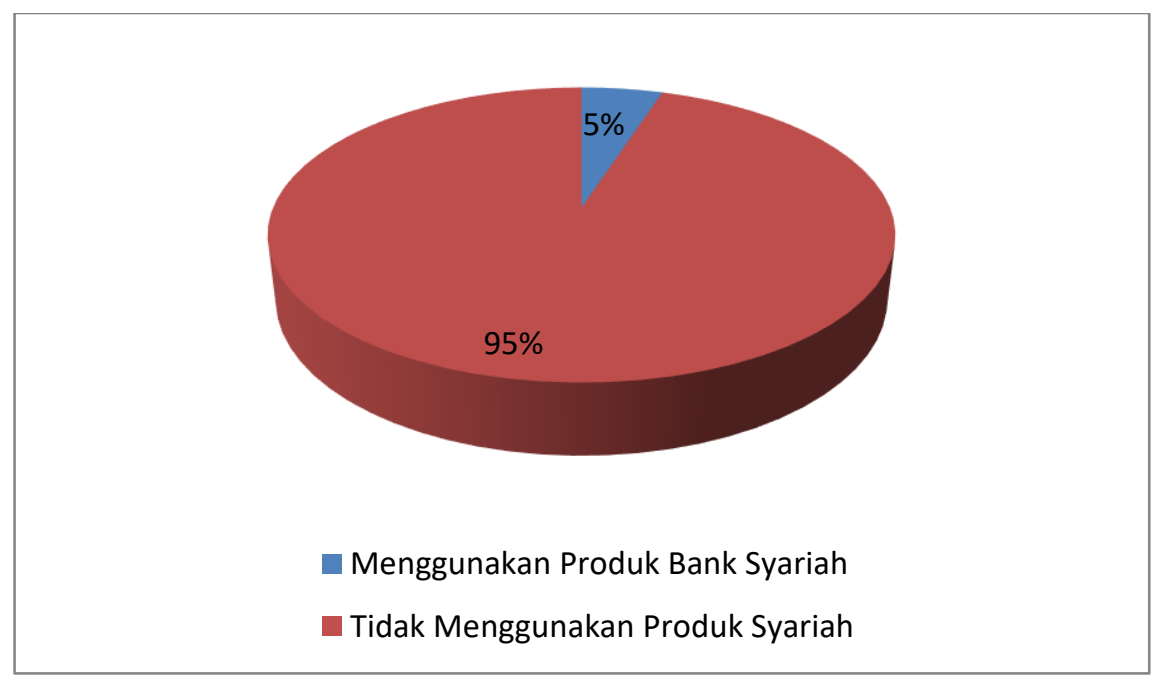

Sumber: data diolah oleh penulis

\section{Pengujian Model Struktural (Inner Model)}

Inner model disebut juga inner relation dan subtrantive theory, dimana model ini akan menggambarkan hubungan antarpeubah atau variabel laten yang didasarkan pada substansi teorinya (Supranto dan Limakrisna 2016). Penilaian pada inner model ini dilakukan dengan melihat model struktural yang dibangun dari konstruk-konstruk laten dalam hipotesis penelitian.

Uji hubungan konstruk laten pada smartPLS menggunakan metode bootstrapping akan memperoleh path coeffisients/S (koefisien jalur) dan juga nilai T-hitung. Setelah itu, siginifikansi atau pentingnya model statistik dalam penelitian dapat dinilai dengan 
menguji besarnya pengaruh konstruk laten dalam hipotesis untuk setiap jalur hubungan menggunakan teknik ini.

Penggunaan uji model struktural ini untuk melihat besarnya hubungan setiap konstruk laten dalam jalur yang terbangun. Hasil uji menunjukkan bahwa niat nelayan untuk mengajukan pembiayaan usaha di bank syariah dipengaruhi oleh variabel-variabel yang diukur menggunakan pendekatan theory of planned behaviour pada model gabungan sampai dengan pemilihan nyata. Hal tersebut menunjukan bahwa nelayan mempunyai persepsi adanya perbedaan antara pembiayaan di bank syariah dengan bank konvensional. Variabel-variabel yang mempunyai pengaruh signifikan terhadap niat nelayan mempunyai syarat nilai $\mathrm{T}$-hitung $>\mathrm{T}$-tabel $=1,96$, sebagaimana dapat dilihat pada Tabel 1 dan Gambar 5 di bawah ini.

Tabel 2. Hasil path coefficient model

\begin{tabular}{|c|c|c|c|}
\hline Jalur & $\begin{array}{l}\text { Original Sample } \\
(O)\end{array}$ & T Statistics $(|O / S T D E V|)$ & $\begin{array}{l}\text { Hasil Uji } \\
\text { Hipotesis }\end{array}$ \\
\hline$S N \rightarrow$ Intention & 0,331 & 3,442 & Terima $H_{1}$ \\
\hline$A T B \rightarrow$ Intention & 0,106 & 0,751 & Tolak $\mathrm{H}_{2}$ \\
\hline$P B C \rightarrow$ Intention & 0,346 & 3,260 & Terima $\mathrm{H}_{3}$ \\
\hline
\end{tabular}

Sumber: data diolah oleh penulis

Tabel 2 di atas menunjukkan adanya pengaruh positif dan signifikan di antara variabel-variabel yang diuji, ditandai dengan melihat nilai yang terdapat pada table original sample $(\mathrm{O})$ dan nilai signifkansi pada tabel T-hitung.

Gambar 4. Hasil Perhitungan T-hitung pada Model

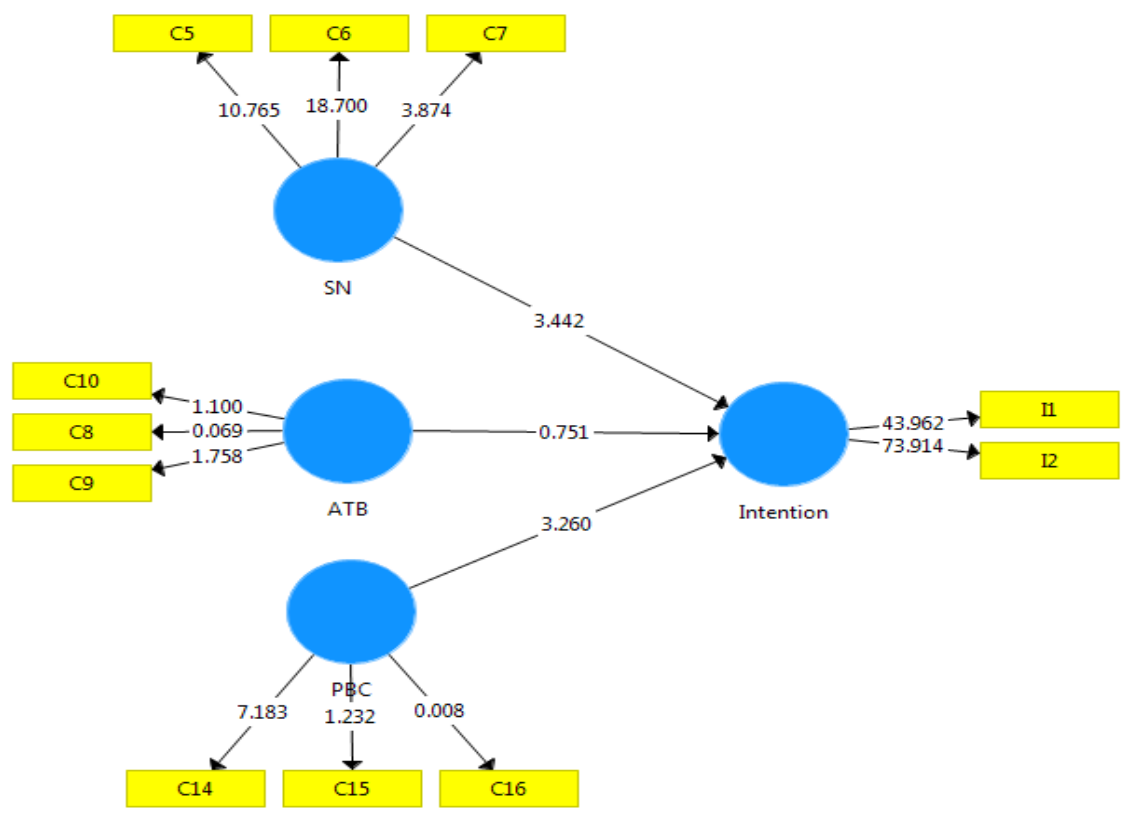

Sumber: data diolah oleh penulis 


\section{Hasil Uji Hipotesis}

Dari tabel 2 dan gambar 4 dapat diketahui bahwa variabel subjective norm (SN) memiliki pengaruh langsung terhadap intention (I) atau niat nelayan untuk mengajukan pembiayaan di bank syariah dengan nilai sebesar 0,331 dan nilai T-hitung sebesar 3,442 (lebih besar dari 1,96). Hasil uji hipotesis 1 menunjukkan bahwa $\mathrm{H}_{0}$ ditolak karena $\mathrm{T}$ hitung > T-tabel. Oleh karena itu, $\mathrm{H}_{1}$ dalam penelitian diterima, yaitu subjective norm berpengaruh terhadap niat nelayan untuk mengajukan pembiayaan di bank syariah.

Indikator pada norma subyektif yang memengaruhi niat nelayan mengajukan pembiayaan di bank syariah berupa ajakan keluarga. Selain itu, ada juga motivasi nelayan untuk mematuhi anjuran keluarga yang akan memengaruhi niat tersebut.

Selanjutnya dapat diketahui bahwa variabel attitude toward behaviour (ATB) tidak memiliki pengaruh langsung terhadap intention (I) atau niat nelayan untuk mengajukan pembiayaan di bank syariah sebesar 0,106 dan nilai T-hitung sebesar 0,751 (lebih kecil dari 1,96). $\mathrm{H}_{0}$ diterima karena $\mathrm{T}$-hitung $<\mathrm{T}$-tabel. Hal ini menunjukkan bahwa $\mathrm{H}_{2}$ dalam penelitian ditolak, yaitu attitude toward behaviour tidak berpengaruh terhadap niat nelayan untuk mengajukan pembiayaan di bank syariah.

Penerapan nilai-nilai ajaran Islam, kepentingan menghindari riba, rentenir, serta judi, dan perbedaan pembiayaan di bank syariah dengan bank konvensional tidak berpengaruh terhadap niat nelayan dalam mengajukan pembiayaan di bank syariah. Ini menunjukkan agama tidak menjadi dasar bagi nelayan untuk mengajukan pembiayaan.

Informasi terakhir yang dapat diketahui dari Tabel 1 dan gambar 5 adalah variabel perceived behavioural control (PBC) memiliki pengaruh langsung terhadap intention (I) sebesar 0,346 dan nilai T-hitung sebesar 3,260 (lebih besar dari 1,96). $\mathrm{H}_{0}$ ditolak karena T-hitung > T-tabel, sehingga $\mathrm{H}_{3}$ diterima, yaitu perceived behavioural control berpengaruh terhadap niat nelayan dalam mengajukan pembiayaan di bank syariah.

Nelayan akan mengajukan pembiayaan ke bank syariah saat hal itu sudah dihadapkan dengan kebutuhannya sebagai seorang muslim. Niat ini akan semakin besar jika mereka sudah mengetahui informasi tentang bank syariah. Informasi yang paling penting buat nelayan adalah bahaya riba dan juga sebagai solusi yang menyelamatkan mereka dari jeratan rentenir.

\section{KESIMPULAN}

Berdasarkan hasil penelitian maka dapat disimpulkan bahwa masih minimnya nelayan di Palabuhanratu yang mengetahui informasi tentang pembiayaan di bank syariah. Selain itu, persepsi nelayan untuk mengajukan pembiayaan di bank syariah dipengaruhi oleh norma subyektif berupa ajakan keluarga dekat serta motivasi untuk mematuhinya dan juga persepsi kontrol perilaku berupa kebutuhannya sebagai seorang muslim.

Implikasi dari penelitian yang diinginkan penulis agar bank syariah dapat melakukan promosi mengenai produknya kepada nelayan di Palabuhanratu. 


\section{REFERENSI}

Asmarani, Ratna. 2012. Faktor-Faktor yang Mempengaruhi Minat Perilaku Dalam Menggunakan Internet Banking. Skripsi. Program Sarjana Fakultas Ekonomi dan Bisnis Universitas Brawijaya.

Chapra MU. 2006. Islam and The Economic Challenge. Terj. Ikhwan Abidin Basri: Islam dan Tantangan Ekonomi. Gema Insani Press. Jakarta.

Fadillah, Nur ATni dan Tuti Kurnia. 2018. Analisis Kebutuhan Nelayan Terhadap Pembiayaan Perbankan Syariah di Pelabuhan Ratu Sukabumi Jawa Barat. Jurnal Nisbah, 4 (2)

Guritno DFER, Bambang Argo Wibowo, dan Herry Boesono. 2014. Analisis Tingkat Kesejahteraan Nelayan Pancing Ulur (Hand Line) di Pelabuhan Perikanan Nusantara (PPN) Palabuhanratu Sukabumi Jawa Barat. Journal of Fisheries Resources Utilization Management and Technology, 3 (3)

Imron, M (2003). Kemiskinan Dalam Masyarakat Nelayan. Jurnal Masyarakat dan Budaya, 5 (1).

Joel, DH. 2017. Manajemen Pendaratan Ikan Pelabuhan Perikanan Nusantara Palabuhanratu Kabupaten Sukabumi Provinsi Jawa Barat. Skripsi. Fakultas Perikanan dan Kelautan, Universitas Riau.

Masyhuri. 2014. Pembiayaan Nonformal Usaha Perikanan Tangkap: Kasus Muncar dan Bitung. Jurnal Ekonomi Pembangunan LIPI, 22 (2).

Mirajiani, Ekawati S. Wahyuni, Arif Satria, Saharuddin, Tridoyo Kusumastanto. 2014. Transformasi Pranata Patronase Masyarakat Nelayan: Dari Ekonomi Moralitas Menuju Ekonomi Pasar. Jurnal Komunitas, 6 (1).

Ranianti, A dan Nirdukita Ratnawati. 2014. Pengaruh Pembiayaan, Dana Pihak Ketiga, dan Non Performing Financing Terhadap Return On Assets Perbankan Syariah di Indonesia 2009-2013: Penerapan Model Simultan. Jurnal Ekonomi Pembangunan Trisakti, 1 (2).

Retnowati E. 2011. Nelayan Indonesia Dalam Pusaran Kemiskinan Struktural (Perspektif Sosial, Ekonomi, dan Hukum). Perspektif. 16 (3).

Tanjung, H dan Abrista Devi. 2013. Metodologi Penelitian Ekonomi Islam. Gramata Publishing. Jakarta.

Setiyowati D, Annisa Febriana Ayub, dan Mochammad Zulkifli. 2016. Statistik Sumber Daya Laut dan Pesisir. Badan Pusat Statistika.

Sumarwan, Ujang. 2011. Perilaku Konsumen. Ghallia Indonesia. Bogor.

Syafrini, Delmira. 2014. Nelayan vs Rentenir, Studi Ketergantungan Nelayan terhadap Rentenir pada Masyarakat Pesisir. Jurnal Ilmu Sosial Mamangan, 1 (2). 